\title{
Chemical characterization and antioxidant potential of native fruits of the Cerrado of northern Minas Gerais
}

\section{Caracterização química e potencial antioxidante de frutos nativos do Cerrado norte mineiro}

\author{
Amanda Laís Alves Almeida Nascimento', Igor Viana Brandi (D), \\ Carla Adriana Ferreira Durães ${ }^{1}$, Juliana Pinto de Lima ${ }^{1}$, Sandro Braga Soares ${ }^{1}$, \\ Bruna Mara Aparecida de Carvalho Mesquita ${ }^{1 *}$ (D)
}

${ }^{1}$ Universidade Federal de Minas Gerais (UFMG), Instituto de Ciências Agrárias, Montes Claros/MG - Brasil

*Corresponding Author: Bruna Mara Aparecida de Carvalho Mesquita, Universidade Federal de Minas Gerais (UFMG), Instituto de Ciências Agrárias, Campus Montes Claros, Avenida Universitária, 1000, Bairro Universitário, CEP: 39404-547, Montes Claros/MG - Brasil, e-mail: brunamara.carvalho@gmail.com

Cite as: Nascimento, A. L. A. A., Brandi, I. V., Durães, C. A. F., Lima, J. P., Soares, S. B., \& Mesquita, B. M. A. C. (2020). Chemical characterization and antioxidant potential of native fruits of the Cerrado of northern Minas Gerais. Brazilian Journal of Food Technology, 23, e2019296. https://doi.org/10.1590/1981-6723.29619

\begin{abstract}
This study aimed to chemically characterize the pulps of the tropical fruits araticum (Annona crassiflora), buriti (Mauritia flexuosa), coquinho azedo (Butia capitata), cagaita (Eugenia dysenterica), and cajá (Spondias mombin), with a focus on antioxidant potential and microminerals. Calcium levels in the Araticum pulp are $9.35 \mathrm{mg} / 100 \mathrm{~g}$ and the iron content was $4.78 \mathrm{mg} / 100 \mathrm{~g}$. In cagaita pulp, the calcium content was $15.35 \mathrm{mg} / 100 \mathrm{~g}$ and magnesium content was $66.00 \mathrm{mg} / 100 \mathrm{~g}$. The iron content present in coquinho pulp was $11.47 \mathrm{mg} / 100 \mathrm{~g}$ and in cagaita it was $11.53 \mathrm{mg} / 100 \mathrm{~g}$. The extracts with the highest contents of total phenolic compounds were araticum (433.80 mg GAE/g) and coquinho (173.5 mg GAE/g). Araticum pulp had the highest antioxidant potential because it had the lowest EC50 $(0.04 \mathrm{mg} / \mathrm{mL})$. The results presented here demonstrate the great potential of the fruits of the Cerrado in terms of rich mineral nutrients and bioactive compounds.
\end{abstract}

Keywords: Bioactive compounds; Micronutrients; Fruit pulp; Araticum; Buriti; Coquinho azedo; Cagaita; Cajá.

\section{Resumo}

O objetivo deste estudo foi caracterizar quimicamente as polpas das frutas tropicais araticum (Annona crassiflora), buriti (Mauritia flexuosa), coquinho-azedo (Butia capitata), cagaita (Eugenia dysenterica) e cajá (Spondias mombin), com foco no potencial antioxidante e nos microminerais. O nível de cálcio na polpa de Araticum foi de $9,35 \mathrm{mg} / 100 \mathrm{~g}$ e o teor de ferro foi de 4,78 mg/100 g. Na polpa de cagaita, o teor de cálcio foi de 15,35 mg/100 g e o de magnésio, $66,00 \mathrm{mg} / 100 \mathrm{~g}$. $O$ teor de ferro presente na polpa de coquinho foi de 11,47 mg/100 g e na polpa de cagaita foi de $11,53 \mathrm{mg} / 100 \mathrm{~g}$. Os extratos com os maiores teores de compostos fenólicos totais foram araticum (433,80 mg GAE/g) e coquinho (173,5 mg GAE/g). A polpa de araticum mostrou o maior potencial antioxidante, pois apresentou a menor EC50 $(0,04 \mathrm{mg} / \mathrm{mL})$. Os resultados encontrados demonstram o grande potencial dos frutos do Cerrado em termos de nutrientes minerais ricos e compostos bioativos.

Palavras-chave: Compostos bioativos; Micronutrientes; Polpa de fruta; Araticum; Buriti; Coquinho-azedo; Cagaita; Cajá. 


\section{Introduction}

The Cerrado is an ecoregion with specific characteristics and great diversity. The richness of native fruit species and a large amount of edible fruit makes the Cerrado the most diversified tropical savanna in the world (Klink \& Machado, 2005; Schiassi et al., 2018).

The greatness of this savannah indicates the importance of studies aimed at the conservation and management of its biodiversity. Fruits are the plant species of the Cerrado, which stand out for their potential for sustainable use.

In addition to its environmental importance, the Cerrado is also a major center for the production of food, fiber, and other products, helping to integrate sustainable development and guaranteeing the quality of life for the population (Avidos \& Ferreira, 2000; Vieira et al., 2006). The native fruits of the Cerrado have great nutritional potential with considerable amounts of protein, fiber, energy content, vitamins, calcium, phosphorus, and fatty acids (Vieira et al., 2006). Data regarding the physicochemical characteristics as well as the nutritional and functional value of the fruits of the Cerrado are essential for boosting the consumption and production of new products with added value (Silva et al., 2008; Morzelle et al., 2015).

Fruits are rich sources of antioxidant compounds, and some studies suggest that the daily intake of antioxidants can effectively protect against oxidative processes (Chen et al., 2014; Lima et al., 2015; Siriamornpun \& Kaewseejan, 2017; Brabo de Sousa et al., 2018). Free radicals and oxidants derive from both internal sources, including metabolism, and external sources (pollution, cigarette smoke, and radiation, among others). Accumulation of these substances can trigger chronic diseases such as cancer, autoimmune diseases, aging processes, cataracts, rheumatoid arthritis, and cardiovascular diseases. Antioxidants are substances that bind radicals, preventing the attacks on lipids, amino acids of proteins and DNA bases, preventing the formation of lesions and the loss of cellular integrity (Van Breda et al., 2008; SuzukiSugihara et al., 2016; Melo et al., 2018).

Phenolic compounds are antioxidants derived from benzoic and cinnamic acids that interact with radical species and are consumed during the reaction; these compounds also act as blockers of chain reactions. They are widely distributed in nature (Moreira \& Mancini-Filho, 2004; Dutra et al., 2017).

Mineral nutrients also play a vital role in the development and proper physiological function, and fruits are considered the main sources of minerals required in human diets. Although quantitatively they represent a small fraction of the total mineral content of the human body, microelements, and trace elements such as zinc, copper manganese, and iron play important roles in several metabolic pathways (Hardisson et al., 2001; Trindade, 2005).

Therefore, the present study was designed to chemically characterize the pulp of araticum, buriti, coquinho azedo, cagaita, and cajá with a focus on their antioxidant potential, their content of phenolic compounds, macronutrients, and minerals.

\section{Materials and methods}

The fruits araticum (Annona crassiflora), buriti (Mauritia flexuosa), coquinho azedo (Butia capitata), cagaita (Eugenia dysenterica), and cajá (Spondias mombin L.), in complete maturation stage, were acquired in cooperative in the city of Montes Claros of the state of Minas Gerais, Brazil (Figure 1) during the harvesting of the year 2018. All analyses were performed in triplicate with 3 replicates. All solvents and reagents used were of analytical grade. 


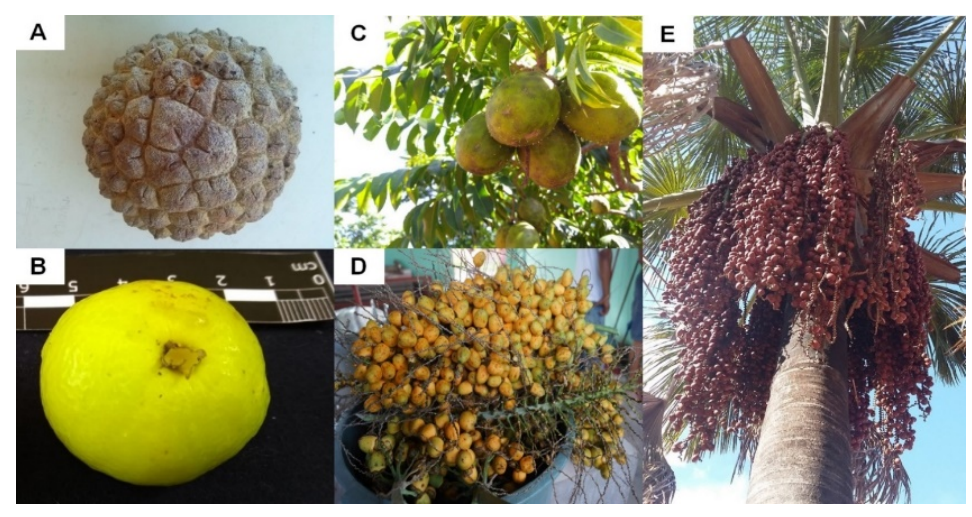

Figure 1. Studied cerrado fruits. (A) Araticum (Annona crassiflora); (B) Cagaita (Eugenia dysenterica); (C) Cajá (Spondias mombin L.); (D) Coquinho azedo (Butia capitata); (E) Buriti (Mauritia flexuosa).

\subsection{Physicochemical analyses}

After extraction of the pulps from the fruits, the moisture (method No. 967.08), ash (method No. 942.05), lipid (method No. 2003.06), and protein (method No. 988.05) contents were determined according to methodologies proposed by the Association of Official Analytical Chemists (AOAC) (Association of Official Analytical Chemists, 2005). The carbohydrate levels were calculated using the following formula: $100-$ (moisture + ash + lipid + protein). The total energy value of the pulp was estimated using the conversion factors of $4 \mathrm{kcal} / \mathrm{g}$ for protein and carbohydrate and $9 \mathrm{kcal} / \mathrm{g}$ for lipid.

Acidity was determined by titration according to Association of Official Analytical Chemists (2005) (method No. 920.124) and was expressed as grams of citric acid per $100 \mathrm{~g}$ of sample. The $\mathrm{pH}$ was determined using a potentiometer (Even model PHS 3E).

Soluble solids were determined using a refractometer (Ávila científica model Biobrix). The color determination was performed using a colorimeter (Konica Miolta model KM- CR-400) by reading the coordinates $\mathrm{L}^{*}, \mathrm{a}^{*}$, and $\mathrm{b}^{*}$. The parameters of hue $\left(\mathrm{h}^{*}\right)$ and saturation $\left(\mathrm{C}^{*}\right)$ were calculated from values of $\mathrm{a}^{*}$ and $\mathrm{b}^{*}$, according to Equations 1 and 2, respectively.

$$
\begin{aligned}
& h^{*}=\arctan \left(\frac{b^{*}}{a^{*}}\right) \\
& c^{*}=\sqrt{a^{* 2}+b^{* 2}}
\end{aligned}
$$

\subsection{Analysis of mineral nutrients}

The samples were digested according to the procedure described by Sobukola et al. (2010). The digestion was carried out with $0.5 \mathrm{~g}$ of dry sample $\left(105^{\circ} \mathrm{C}\right.$ for 24 hours $), 2.5 \mathrm{~mL}$ of $\mathrm{HCl}, 1 \mathrm{~mL}^{\circ} \mathrm{H}_{2} \mathrm{SO}_{4}$, and $10 \mathrm{~mL}$ of $\mathrm{HNO}_{3}$ on a heating plate for $30 \mathrm{~min}$ at $180^{\circ} \mathrm{C}$.

Calcium $(\mathrm{Ca})$, magnesium $(\mathrm{Mg})$, iron $(\mathrm{Fe})$, manganese $(\mathrm{Mn})$, copper $(\mathrm{Cu})$, and zinc $(\mathrm{Zn})$ were analyzed by atomic absorbance spectroscopy (Varian, model AAS $240 \mathrm{FS}$ ). Sodium (Na) was analyzed by flame photometry.

\subsection{Preparation of the methanolic-acetanolic extracts}

For the analysis of total phenolic compounds and total antioxidant activity, we obtained extracts of fruit pulp according to a method adapted from Rufino et al. (2007). Five grams of each sample was diluted in $10 \mathrm{~mL}$ of $50 \%$ methanol. After standing for 1 hour, it was centrifuged at $4000 \mathrm{rpm}$ for 30 minutes (Kacil centrifuge model CEO1). The supernatant was transferred to a $25 \mathrm{~mL}$ flask. To the precipitate, we added 
$10 \mathrm{~mL}$ of $70 \%$ acetone and homogenized again. After 1 hour of standing it was centrifuged again at $4000 \mathrm{rpm}$ for 30 minutes. The supernatant was transferred to the flask and the volume was brought to $25 \mathrm{~mL}$.

\subsection{Total phenolic compounds}

Analysis of total phenolic compounds was adapted from Singleton \& Rossi (1965). For the reaction, $0.5 \mathrm{~mL}$ of sample extract, $2.5 \mathrm{~mL}$ of Folin-Ciocalteu solution (10\%), and $2 \mathrm{~mL}$ of sodium carbonate solution (4\%) were used. After 2 hours, a spectrophotometer (Nova model 1600UV) reading at $750 \mathrm{~nm}$ was performed. The phenolic content was calculated using a standard curve prepared with gallic acid and expressed in $\mathrm{mg}$ of gallic acid equivalent (GAE)/100 g.

\subsection{Antioxidant capacity}

For the determination of the antioxidant capacity (AC) we used a methodology described by Re et al. (1999), with adaptations. This methodology proposes that the stable radical purple DPPH decolorizes in reactions with antioxidants present in the sample, thus the higher the antioxidant capacity of the sample, the greater the loss of DPPH reagent staining with a consequent decrease in absorbance reading.

To prepare the curves for each fruit, $0.1 \mathrm{~mL}$ of the extract of the samples described in section 2.3 at various dilutions and $3.9 \mathrm{~mL}$ of DPPH solution were used. The reading was made after 1 hour and 30 minutes of reaction. This time was determined after preliminary tests of the stabilization of the spectrophotometer (Nova model 1600UV) readings.

The $\mathrm{EC}_{50}$ calculation for the percentage of radical oxidation inhibition was calculated using Equation 3.

$\%$ Inhibition $=\left(\left(A b s_{D P P H}-A b s_{E x t r}\right) / A b s_{D P P H}\right) * 100$

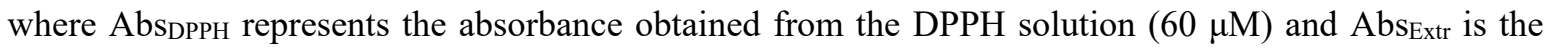
absorbance of the extract from each sample.

\subsection{Statistical analysis}

The results were subjected to analysis of variance (ANOVA) and the mean values were compared to the confidence level of $95 \%(p<0.05)$ by the Tukey test. We used the statistical software package SAS, Statistical Analysis System, version 9.1.

The correlation between TAC and the total phenolic compound content was calculated using the statistical package Bioestat, version 5.3, at a 5\% significance level.

\section{Results and discussion}

The centesimal composition and caloric value of the analyzed fruit pulps are presented in Table 1.

Table 1. Centesimal composition and calorific value of fruit pulps of the Cerrado of northern Minas Gerais -Brazil.

\begin{tabular}{|c|c|c|c|c|c|c|}
\hline Fruit pulps & $\begin{array}{l}\text { Moisture } \\
(\% \mathrm{~m} / \mathbf{m})\end{array}$ & $\begin{array}{l}\text { Protein } \\
(\% \mathrm{~m} / \mathbf{m})\end{array}$ & $\begin{array}{c}\text { Ash } \\
(\% \mathrm{~m} / \mathrm{m})\end{array}$ & $\begin{array}{c}\text { Lipids } \\
(\% \mathrm{~m} / \mathrm{m})\end{array}$ & $\begin{array}{c}\text { Total } \\
\text { carbohydrates } \\
(\% \mathbf{m} / \mathbf{m})\end{array}$ & $\begin{array}{c}\text { Caloric value } \\
\text { (kcal/100 g) }\end{array}$ \\
\hline Araticum & $71.42 \pm 0.39^{\mathrm{d}}$ & $1.51 \pm 0.22^{\mathrm{a}}$ & $0.54 \pm 0.02^{\mathrm{a}}$ & $3.11 \pm 0.04^{\mathrm{b}}$ & $23.42 \pm 0.20^{\mathrm{a}}$ & $127.71 \pm 1.75^{b}$ \\
\hline Buriti & $70.65 \pm 0.19^{\mathrm{e}}$ & $1.26 \pm 0.37^{\mathrm{ab}}$ & $0.56 \pm 0.03^{\mathrm{a}}$ & $11.29 \pm 0.08^{\mathrm{a}}$ & $16.24 \pm 0.39^{b}$ & $171.61 \pm 1.20^{\mathrm{a}}$ \\
\hline Cagaita & $92.44 \pm 0.27^{\mathrm{a}}$ & $1.14 \pm 0.29^{\mathrm{ab}}$ & $0.04 \pm 0.01^{\mathrm{c}}$ & $0.05 \pm 0.01^{\mathrm{d}}$ & $6.33 \pm 0.46^{\mathrm{d}}$ & $30.33 \pm 1.04^{\mathrm{e}}$ \\
\hline Cajá & $84.87 \pm 0.35^{\mathrm{c}}$ & $0.86 \pm 0.20^{\mathrm{ab}}$ & $0.17 \pm 0.05^{b}$ & $0.03 \pm 0.02^{\mathrm{d}}$ & $14.07 \pm 0.34^{\mathrm{c}}$ & $59.99 \pm 1.29^{c}$ \\
\hline Coquinho & $90.00 \pm 0.06^{\mathrm{e}}$ & $0.83 \pm 0.07^{b}$ & $0.54 \pm 0.07^{\mathrm{a}}$ & $2.62 \pm 0.14^{\mathrm{c}}$ & $6.01 \pm 0.12^{\mathrm{d}}$ & $50.94 \pm 1.08^{\mathrm{d}}$ \\
\hline
\end{tabular}

Legend: mean \pm standard deviation $(\mathrm{n}=3)$. The averages with the same letters in the column do not differ by the Tukey test $(p \geq 0.05)$. 
We observed that all the analyzed pulps had high levels of moisture varying from $70.65 \%$ for buriti to $92.44 \%$ for cagaita. The pulp that presented the highest protein content was araticum $(1.51 \%)$ and the lowest was coquinho $(0.83 \%)$. The value found for buriti pulp (1.26\%) was below the value found by Manhães \& Sabaa-Srur (2011), which was $2.10 \%$ for buriti in the region of Pará-BR. In general, these differences in composition can be the result of several factors, including the place of cultivation, temperature, degree of maturity, etc. The pulps with the highest ash contents were araticum $(0.54 \%)$, buriti $(0.56 \%)$, and coquinho $(0.54 \%)$. The lowest ash value was found in cagaita pulp $(0.04 \%)$.

The highest lipid content was found for buriti $(11.29 \%)$. This fruit is naturally oily and is exploited for this characteristic in oil production. The high lipid content of buriti gives this pulp a characteristically higher caloric value among the analyzed pulps. Cajá $(0.03 \%)$ and cagaita $(0.05 \%)$ were the pulps with the lowest lipid content.

The pulps were rich in water and total carbohydrates, including fibers and sugars. They all had low caloric value, except for buriti $(171.61 \mathrm{kcal} / 100 \mathrm{~g})$ which stands out for its richness in lipids. Araticum also had a high caloric value $(127.71 \mathrm{kcal} / 100 \mathrm{~g})$, because it had a high total carbohydrate content compared to other analyzed pulps.

The differences between our results regarding chemical composition and values reported in studies of other authors are due to variations of factors such as degree of maturity, harvest season, location, and climate (Ferrão et al., 2013; Siriamornpun \& Kaewseejan, 2017). Table 2 shows the results of soluble solids, pH, acidity, and color.

For soluble solids, the sample with the highest value was araticum ( $\left.17.37^{\circ} \mathrm{Brix}\right)$ value less than the value reported by Cardoso et al. (2013) (22.54 ${ }^{\circ}$ Brix), but higher than the value reported by Souza et al. (2012) $\left(11.33^{\circ} \mathrm{Brix}\right)$. These differences can occur due to several factors including place of cultivation, climate, time of harvest, and degree of maturation. The pulp with the highest acidity was cajá, with $1.21 \mathrm{~g} / 100 \mathrm{~g}$.

The values of $\mathrm{pH}$ varied between 2.49 and 4.17 for cajá and buriti, respectively. The $\mathrm{pH}$ values for cagaita (4.02) and araticum (3.07) differed from those reported by Roesler et al. (2007), which were 2.8 and 4.8, respectively.

Table 2. Physicochemical properties of fruit pulps from the Cerrado of northern Minas Gerais.

\begin{tabular}{ccccccc}
\hline Fruit pulps & $\begin{array}{c}\text { Soluble solids } \\
\left({ }^{\circ} \mathbf{B r i x}\right)\end{array}$ & $\mathbf{p H}$ & $\begin{array}{c}\text { Titratable acidity } \\
\mathbf{( g / 1 0 0} \mathbf{g})\end{array}$ & $\mathbf{L}^{*}$ & $\mathbf{C}^{*}$ & $\mathbf{h}^{*}$ \\
\hline Araticum & $17.37 \pm 0.58^{\mathrm{a}}$ & $4.02 \pm 0.02^{\mathrm{a}}$ & $0.45 \pm 0.02^{\mathrm{c}}$ & $58.19 \pm 0.95^{\mathrm{a}}$ & $8.41 \pm 0.06^{\mathrm{b}}$ & $75.45 \pm 0.01^{\mathrm{b}}$ \\
\hline Buriti & $2.17 \pm 0.29^{\mathrm{d}}$ & $4.17 \pm 0.26^{\mathrm{a}}$ & $0.73 \pm 0.09^{\mathrm{b}}$ & $38.50 \pm 1.01^{\mathrm{d}}$ & $8.58 \pm 0.14^{\mathrm{b}}$ & $68.63 \pm 0.02^{\mathrm{c}}$ \\
\hline Cagaita & $5.40 \pm 0.36^{\mathrm{c}}$ & $3.07 \pm 0.06^{\mathrm{c}}$ & $0.31 \pm 0.01^{\mathrm{d}}$ & $50.62 \pm 0.35^{\mathrm{b}}$ & $6.59 \pm 0.68^{\mathrm{c}}$ & $-79.73 \pm 0.02^{\mathrm{e}}$ \\
\hline Cajá & $15.17 \pm 0.14^{\mathrm{b}}$ & $2.49 \pm 0.01^{\mathrm{d}}$ & $1.21 \pm 0.01^{\mathrm{a}}$ & $42.60 \pm 0.10^{\mathrm{c}}$ & $6.79 \pm 0.05^{\mathrm{c}}$ & $-86.87 \pm 0.00^{\mathrm{d}}$ \\
\hline Coquinho & $5.75 \pm 0.00^{\mathrm{c}}$ & $3.41 \pm 0.01^{\mathrm{b}}$ & $1.16 \pm 0.01^{\mathrm{a}}$ & $56.53 \pm 0.10^{\mathrm{a}}$ & $10.65 \pm 0.01^{\mathrm{a}}$ & $81.94 \pm 0.00^{\mathrm{a}}$ \\
\hline
\end{tabular}

Legend: $\mathrm{L}^{*}$ (Luminosity); $\mathrm{C}^{*}$ (Saturation); $\mathrm{h}$ (Tonality). Mean \pm Standard Deviation $(\mathrm{n}=3)$. The averages with the same letters in the column do not differ by the Tukey test $(p \geq 0.05)$.

The Normative Instruction No. 37, of October 1, 2018, from the Ministry of Agriculture, Livestock and Supply, provided parameters for quality and identity of various fruit pulps including buriti and cajá. According to this Normative Instruction (Brasil, 2018), the minimum values for soluble solids in buriti pulp were $4.5^{\circ} \mathrm{Brix}, \mathrm{pH} 3.5$, and total acids $2.2 \mathrm{~g} / 100 \mathrm{~g}$. The values we reported for buriti samples would therefore be characterized as non-standard. For the pulp of the cajá, the minimum values were soluble solids $9.0^{\circ} \mathrm{Brix}$, $\mathrm{pH} 2.2$, and total acids $0.9 \mathrm{~g} / 100 \mathrm{~g}$. Therefore, our cajá sample analyzed met all parameters. The other pulps studied did not have parameters of quality and identity foreseen in the Brazilian legislation (Brasil, 2018).

The values of luminosity $\left(\mathrm{L}^{*}\right)$ showed that the pulps with the darkest coloration were those of buriti $(38.50)$ and cajá (42.60) with the lowest values of $L^{*}$. Saturation values $\left(C^{*}\right)$ varied from 0 to 100 with higher values 
indicating a more intense color. The values presented by the analyzed pulps are considered low, suggesting that they are not pure colors but rather were a mixture of shades. The parameter tonality $\left(\mathrm{h}^{*}\right)$ shows that the pulp of araticum and coquinho tended to be yellow, the pulps of cagaita and cajá demonstrated green shades and the pulp of buriti tended toward red tones. However, because the values of $\mathrm{C}^{*}$ were low, these colors are not pure, i.e., they showed tendencies toward these tones.

Table 3 shows the results of the mineral analysis of the pulps of the fruits studied. For each fruit and mineral, the Dietary Reference Intake (DRI) for a healthy male adult was calculated. For calcium, magnesium, and zinc, the $\mathrm{FAO} / \mathrm{WHO}$ reference values (Food and Agriculture Organization of the United Nations, 2001) were used, and the reference values of the Institute of Medicine (2001) were used for copper and manganese.

Magnesium was the element with the greatest concentration among the analyzed elements in the pulps studied. The pulp of cagaita had the highest magnesium content $(66.00 \mathrm{mg} / 100 \mathrm{~g})$ representing about $25 \%$ of the recommended daily intake.

In addition to calcium being an important metal in the development and maintenance of bones and teeth, is also necessary for processes that carry ions through cell membranes and for the regulation of cardiac muscle function. Buriti $(36.93 \mathrm{mg} / 100 \mathrm{~g})$ and coquinho $(31.64 \mathrm{mg} / 100 \mathrm{~g})$ had the highest content of calcium. Schiassi et al. (2018) reported similar values for buriti $(37.83 \mathrm{mg} / 100 \mathrm{~g})$. However, the value obtained was well below that found by Manhães \& Sabaa-Srur (2011) for buriti in the region of Pará-BR $(80.49 \mathrm{mg} / 100 \mathrm{~g})$. As previously mentioned, these results demonstrate that the composition of these fruits varies considerably depending on the region of cultivation.

Table 3. Concentration of metals and \% DRI in fruit pulps from the Cerrado of northern Minas Gerais.

\begin{tabular}{|c|c|c|c|c|c|c|c|}
\hline $\begin{array}{l}\text { Fruit } \\
\text { pulps }\end{array}$ & $\begin{array}{l}\text { Sodium* } \\
(\mathrm{mg} / 100 \mathrm{~g})\end{array}$ & $\begin{array}{c}\text { Calcium } \\
(\mathrm{mg} / \mathbf{1 0 0} \mathrm{g})\end{array}$ & $\begin{array}{c}\text { Magnesium } \\
(\mathrm{mg} / 100 \mathrm{~g})\end{array}$ & $\begin{array}{c}\text { Zinc } \\
(\mathrm{mg} / \mathbf{1 0 0} \mathrm{g})\end{array}$ & $\begin{array}{c}\text { Iron } \\
(\mathrm{mg} / 100 \mathrm{~g})\end{array}$ & $\begin{array}{c}\text { Copper } \\
(\mathrm{mg} / \mathbf{1 0 0} \mathrm{g})\end{array}$ & $\begin{array}{c}\text { Manganese } \\
\text { (mg/100 g) }\end{array}$ \\
\hline Araticum & $3.72 \pm 1.26^{\mathrm{a}}$ & $9.35 \pm 0.86^{\mathrm{c}}$ & $56.67 \pm 2.36^{\mathrm{a}}$ & $0.35 \pm 0.08^{\mathrm{d}}$ & $4.78 \pm 0.52^{b}$ & $0.61 \pm 0.01^{\mathrm{b}}$ & $0.60 \pm 0.01^{\mathrm{c}}$ \\
\hline$\%$ DRI & - & 1 & 22 & 5 & 34 & 67 & 26 \\
\hline Buriti & $6.30 \pm 0.41^{\mathrm{a}}$ & $36.93 \pm 0.64^{\mathrm{a}}$ & $37.33 \pm 2.93^{b}$ & $1.13 \pm 0.04^{b}$ & $2.37 \pm 0.62^{c}$ & $0.35 \pm 0.03^{\mathrm{c}}$ & $4.69 \pm 0.34^{\mathrm{a}}$ \\
\hline$\%$ DRI & - & 4 & 14 & 16 & 17 & 39 & 204 \\
\hline Cagaita & $6.63 \pm 1.36^{\mathrm{a}}$ & $15.35 \pm 2.23^{\mathrm{c}}$ & $66.00 \pm 6.06^{\mathrm{a}}$ & $2.31 \pm 0.10^{\mathrm{a}}$ & $11.53 \pm 1.82 \mathrm{a}$ & $0.63 \pm 0.02^{\mathrm{b}}$ & $1.56 \pm 0.07^{\mathrm{b}}$ \\
\hline$\%$ DRI & - & 2 & 25 & 33 & 82 & 69 & 68 \\
\hline Cajá & $4.16 \pm 0.68^{\mathrm{a}}$ & $23.66 \pm 3.12^{b}$ & $45.50 \pm 2.12^{\mathrm{ab}}$ & $0.06 \pm 0.06^{\mathrm{d}}$ & $1.22 \pm 0.44^{\mathrm{c}}$ & $0.24 \pm 0.01^{\mathrm{d}}$ & $0.42 \pm 0.01^{\mathrm{c}}$ \\
\hline$\%$ DRI & - & 2 & 18 & 1 & 9 & 27 & 18 \\
\hline Coquinho & $6.64 \pm 0.06^{\mathrm{a}}$ & $31.64 \pm 4.22^{\mathrm{a}}$ & $62.50 \pm 1.80^{\mathrm{a}}$ & $0.69 \pm 0.06^{\mathrm{c}}$ & $11.47 \pm 1.60^{\mathrm{a}}$ & $0.69 \pm 0.02^{\mathrm{a}}$ & $1.79 \pm 0.04^{\mathrm{b}}$ \\
\hline$\%$ DRI & - & 3 & 24 & 10 & 82 & 76 & 78 \\
\hline
\end{tabular}

Legend: DRI (Dietary Reference Intake). \% DRI about $100 \mathrm{~g}$ pulp. *For sodium, there is a recommended upper limit of $2400 \mathrm{mg}$. Mean \pm Standard Deviation $(\mathrm{n}=3)$. The averages with the same letters in the column do not differ by the Tukey test $(p \geq 0.05)$. Source: $\%$ DRI calcium, iron, magnesium, and zinc (Food and Agriculture Organization of the United Nations, 2001); Copper and manganese (Institute of Medicine, 2001).

Sodium, unlike other minerals, is analyzed according to its upper limit, because excessive intake is linked to hypertension. This daily limit is $2400 \mathrm{mg}$ (Mahan et al., 2005). All analyzed pulps had less than $1 \%$ of the maximum permitted intake. There was no statistical difference in sodium content among the samples.

Zinc, copper, iron, and manganese are considered microminerals because they are present in minute amounts in body tissues. The pulp of cagaita had the highest content of zinc $(2.31 \mathrm{mg} / 100 \mathrm{~g})$, representing $33 \%$ of the DRI. Silva et al. (2008) did not find zinc in cagaita. For araticum, this same researcher found 
$0.79 \mathrm{mg} / 100 \mathrm{~g}$, while in the present study the value found for zinc in araticum was $0.35 \mathrm{mg} / 100 \mathrm{~g}$. The pulps with the lowest zinc content were cajá $(0.06 \mathrm{mg} / 100 \mathrm{~g})$ and araticum $(0.35 \mathrm{mg} / 100 \mathrm{~g})$.

The pulps of cagaita and coquinho had the highest contents of iron at $11.53 \mathrm{mg} / 100 \mathrm{~g}$ and $11.47 \mathrm{mg} / 100 \mathrm{~g}$, respectively. These values represent about $82 \%$ of the recommended daily intake. Coquinho pulp also had the highest copper $(0.69 \mathrm{mg} / 100 \mathrm{~g})$. Cajá pulp had the lowest copper content $(0.24 \mathrm{mg} / 100 \mathrm{~g})$.

Buriti pulp had the highest manganese content $(4.69 \mathrm{mg} / 100 \mathrm{~g})$. This value was higher than that reported by Manhães \& Sabaa-Srur (2011) (1.79 mg/100 g). The value found for manganese in buriti was above the recommended value for daily intake of this mineral, however, the maximum tolerable levels of intake of this mineral are $11 \mathrm{mg}$ per day (Institute of Medicine, 2001).

The results of analyses of phenolic compound content and antioxidant capacity are shown in Table 4.

The extracts with the highest values of total phenolic compounds were those of araticum (433.80 mg GAE/g). Cajá (58.27 mg GAE/g) and buriti (90.24 mg GAE/g) had the lowest content of phenolic compounds.

The pulps of araticum, coquinho, and cagaita presented high phenolic contents when compared to other traditional fruit pulps such as tamarind (23.57 mg GAE/g), caju (201.61 mg GAE/g), and goiaba (104.79 mg $\mathrm{GAE} / \mathrm{g}$ ) reported by Vieira et al. (2011). For cajá, this same researcher found $70.92 \mathrm{mg} \mathrm{GAE} / \mathrm{g}$. This value was higher than the value we reported in the present study $(58.3 \mathrm{mg} \mathrm{GAE} / \mathrm{g})$. The content of phenolic compounds in fruits varies widely with the species of the crop, the local the time of the harvest, and season of the year. In general, the high total phenolic content observed in the present study demonstrates the great potential in bioactive compounds presented by the fruits of the Cerrado of northern Minas Gerais.

Table 4. Total phenolic content and antioxidant capacity of native fruits of the Cerrado of northern Minas Gerais.

\begin{tabular}{|c|c|c|}
\hline Fruit pulp & Total phenolics (mg GAE/100 g) & $\mathrm{EC}_{50}(\mathrm{mg} / \mathrm{mL})$ \\
\hline Araticum & $433.75 \pm 0.07^{\mathrm{a}}$ & $0.04 \pm 0.04^{\mathrm{d}}$ \\
\hline Buriti & $90.24 \pm 0.01^{\mathrm{c}}$ & $3.27 \pm 0.25^{\mathrm{b}}$ \\
\hline Cagaita & $143.81 \pm 0.03^{b}$ & $0.73 \pm 0.08^{c}$ \\
\hline Cajá & $58.27 \pm 0.01^{\mathrm{c}}$ & $4.68 \pm 0.06^{\mathrm{a}}$ \\
\hline Coquinho & $173.49 \pm 0.06^{\mathrm{b}}$ & $0.77 \pm 0.12^{\mathrm{c}}$ \\
\hline
\end{tabular}

Legend: GAE: Gallic acid equivalent; Total phenolics per 100 grams of fruit pulp. Antioxidant capacity (AC) expressed in $\mathrm{EC}_{50}$. Mean \pm Standard Deviation $(\mathrm{n}=3)$. The averages with the same letters in the column do not differ by the Tukey test $(p \geq 0.05)$.

The analysis was used for $\mathrm{AC}$ determination based on the transfer of electrons between antioxidants in the sample and the stable radical DPPH. This reaction discolors the purple DPPH reagent, causing a decrease in absorbance with increasing antioxidant potential. Therefore, samples with the lowest content of $\mathrm{EC}_{50}$ were those that presented the highest AC (Table 4).

Araticum pulp had the lowest $\mathrm{EC}_{50}$ value $(0.04 \mathrm{mg} / \mathrm{mL})$ and, consequently, the highest antioxidant potential. Cajá pulp had the highest $\mathrm{EC}_{50}$ value $(4.68 \mathrm{mg} / \mathrm{mL})$, and therefore the lowest antioxidant potential.

Roesler et al. (2007) found that araticum pulp had an $\mathrm{EC}_{50}$ value of $0.14882 \mathrm{mg} / \mathrm{mL}$, higher than the value obtained in the present study $(0.04 \mathrm{mg} / \mathrm{mL})$. For cagaita, this same researcher found $\mathrm{EC}_{50}$ of $0.387 \mathrm{mg} / \mathrm{mL}$, slightly lower than the value presented in this study $(0.73 \mathrm{mg} / \mathrm{mL})$.

The correlation found between AC and total phenolic compounds content was negative and of high magnitude, but was not significant $(\mathrm{r}=-0.7343 ; p=0.3751)$, that is, as the content of phenolic compounds increases, antioxidant activity increases. However, when the correlation was tested without the data obtained for the araticum pulp, the correlation increased $(\mathrm{r}=-0.9717 ; p=0.6833)$. The antioxidant capacity of the 
araticum pulp is probably linked to other groups such as carotenoids, chlorophyll, and vitamins, among others.

\section{Conclusion}

Cerrado fruit pulps were high in water and carbohydrates. Buriti pulp had the highest lipid content. In general, caloric values were highest for buriti and araticum. The highest iron content in the pulps was found in coquinho and cagaita. Araticum and cagaita had the highest antioxidant capacity. The pulps with the highest content of phenolic compounds were araticum and coquinho.

This study provides important information regarding these Cerrado fruit pulps. We highlighted their great nutritional and bioactive potential that can be exploited by industry to add value to products and to add value to their origin, the Cerrado.

\section{Acknowledgements}

To UFMG, FAPEMIG and CNPq for financial support of this research.

\section{References}

Association of Official Analytical Chemists - AOAC. (2005). Official methods of analysis of the Association of Official Analytical Chemists (18th ed.). Gaithersburg: AOAC.

Avidos, M. F. D., \& Ferreira, L. T. (2000). Frutos dos cerrados: Preservação gera muitos frutos. Biotecnologia Ciencia \& Desenvolvimento, 3(15), 36-41.

Brabo de Sousa, S. H., Andrade Mattietto, R., Campos Chisté, R., \& Carvalho, A. V. (2018). Phenolic compounds are highly correlated to the antioxidant capacity of genotypes of Oenocarpus distichus Mart. fruits. Food Research International, 108, 405-412. PMid:29735073. http://dx.doi.org/10.1016/j.foodres.2018.03.056

Brasil. Ministério da Agricultura, Pecuária e Abastecimento. Secretaria de Defesa Agropecuária. (2018, outubro 8). Aprova Instrução Normativa e Anexos - Estabelecer, na forma dos Anexos desta Instrução Normativa, os parâmetros analíticos de suco e de polpa de frutas e a listagem das frutas e demais quesitos complementares aos padrões de identidade e qualidade (Instrução normativa $n^{\circ} 37$, de 1 de outubro de 2018). Diário Oficial [da] República Federativa do Brasil, Brasília. Retrieved in 2019, October 29, from http://pesquisa.in.gov.br/imprensa/jsp/visualiza/index.jsp?data=08/10/2018\&jornal=515\&pagina=23

Cardoso, L. M., Oliveira, D. S., Bedetti, S. F., Martino, H. S. D., \& Pinheiro-Sant'Ana, H. M. (2013). Araticum (Annona crassiflora Mart.) from the Brazilian Cerrado: Chemical composition and bioactive compounds. Fruits, 68(2), 121-134. http://dx.doi.org/10.1051/fruits/2013058

Chen, G.-L., Chen, S.-G., Zhao, Y.-Y., Luo, C.-X., Li, J., \& Gao, Y.-Q. (2014). Total phenolic contents of 33 fruits and their antioxidant capacities before and after in vitro digestion. Industrial Crops and Products, 57, 150-157. http://dx.doi.org/10.1016/j.indcrop.2014.03.018

Dutra, R. L. T., Dantas, A. M., Marques, D. A., Batista, J. D. F., Meireles, B. R. L. A., Magalhães Cordeiro, A. M. T., Magnani, M., \& Borges, G. D. S. C. (2017). Bioaccessibility and antioxidant activity of phenolic compounds in frozen pulps of Brazilian exotic fruits exposed to simulated gastrointestinal conditions. Food Research International, 100(Pt 1), 650-657. PMid:28873733. http://dx.doi.org/10.1016/j.foodres.2017.07.047

Ferrão, T. S., Ferreira, D. F., Flores, D. W., Bernardi, G., Link, D., Barin, J. S., \& Wagner, R. (2013). Evaluation of composition and quality parameters of jelly palm (Butia odorata) fruits from different regions of Southern Brazil. Food Research International, 54(1), 57-62. http://dx.doi.org/10.1016/j.foodres.2013.06.002

Food and Agriculture Organization of the United Nations - FAO. World Health Organization - WHO. (2001). Human vitamin and mineral requirements: Report of $7^{a}$ Joint FAO/WHO Expert Concultation. Bangkok: FAO/WHO.

Hardisson, A., Rubio, C., Baez, A., Martin, M., Alvarez, R., \& Diaz, E. (2001). Mineral composition of the banana (Musa acuminata) from the island of Tenerife. Food Chemistry, 73(2), 153-161. http://dx.doi.org/10.1016/S0308-8146(00)00252-1

Institute of Medicine. (2001). Food and nutrition board: Dietary reference intakes for vitamin A, vitamin K, arsenic, boron, chromium, copper, iodine, iron, manganese, molybdenum, nickel, silicon, vanadium, and zinc. Washington, D.C.: National Academies Press https://doi.org/10.17226/10026.

Klink, C. A., \& Machado, R. B. (2005). A conservação do Cerrado brasileiro. Revista Megadiversidade, 1(1), 147-155.

Lima, J. P., Azevedo, L., de Souza, N. J., Nunes, E. E., \& Vilas Boas, E. V. (2015). First evaluation of the antimutagenic effect of mangaba fruit in vivo and its phenolic profile identification. Food Research International, 75, 216-224. PMid:28454950. http://dx.doi.org/10.1016/j.foodres.2015.05.045

Mahan, L. K., Escott-Stump, S., \& Raymond, J. L. (2005) Krause, alimentos, nutrição e dietoterapia (14. ed.) Rio de Janeiro: Elsevier. 
Manhães, L. R. T., \& Sabaa-Srur, A. U. O. (2011). Centesimal composition and bioactive compounds in fruits of buriti collected in Pará. Food Science and Technology, 31(4), 856-863. http://dx.doi.org/10.1590/S0101-20612011000400005

Melo, M. N. O., Oliveira, A. P., Wiecikowski, A. F., Carvalho, R. S., Castro, J. L., Oliveira, F. A. G., Pereira, H. M. G., Veiga, V. F., Capella, M. M. A., Rocha, L., \& Holandino, C. (2018). Phenolic compounds from Viscum album tinctures enhanced antitumor activity in melanoma murine cancer cells. Saudi Pharmaceutical Journal, 26(3), 311-322. PMid:29556122. http://dx.doi.org/10.1016/j.jsps.2018.01.011

Moreira, A. V. B., \& Mancini-Filho, J. (2004). Influência dos compostos fenólicos de especiarias sobre a lipoperoxidação e o perfil lipídico de tecidos de ratos. Revista de Nutrição, 17(4), 411-424. http://dx.doi.org/10.1590/S1415-52732004000400002

Morzelle, M. C., Bachiega, P., Souza, E. C., Vilas Boas, E. V. D. B., \& Lamounier, M. L. (2015). Caracterização química e física de frutos de curriola, gabiroba e murici provenientes do cerrado brasileiro. Revista Brasileira de Fruticultura, 37(1), 96-103. http://dx.doi.org/10.1590/0100-2945-036/14

Re, R., Pellegrini, N., Proteggente, A., Pannala, A., Yang, M., \& Rice-Evans, C. (1999). Antioxidant activity applying an improved ABTS radical cation decolorization assay. Free Radical Biology \& Medicine, 26(9-10), 1231-1237. PMid:10381194. http://dx.doi.org/10.1016/S0891-5849(98)00315-3

Roesler, R., Malta, L. G., Carrasco, L. C., Holanda, R. B., Sousa, C. A. S., \& Pastore, G. M. (2007). Atividade antioxidante de frutas do cerrado. Food Science and Technology, 27(1), 53-60. http://dx.doi.org/10.1590/S0101-20612007000100010

Rufino, M. S. M., Alves, R. E., Brito, E. S., Morais, S. M., Sampaio, C. G., Pérez-Jiménez, J., \& Saura-Calixto, F. D. (2007). Metodologia científica: Determinação da atividade antioxidante total em frutas pela captura do radical livre DPPH (4 p.). Fortaleza: EMBRAPA. Retrieved in 2019, October 29, from https://ainfo.cnptia.embrapa.br/digital/bitstream/CNPAT/10224/1/Cot_127.pdf

Schiassi, M. C. E. V., Souza, V. R., Lago, A. M. T., Campos, L. G., \& Queiroz, F. (2018). Fruits from the Brazilian Cerrado region: Physico-chemical characterization, bioactive compounds, antioxidant activities, and sensory evaluation. Food Chemistry, 245, 305311. PMid:29287376. http://dx.doi.org/10.1016/j.foodchem.2017.10.104

Silva, M. R., Lacerda, D. B. C. L., Santos, G. G., \& Martins, D. M. de O. (2008). Caracterização química de frutos nativos do cerrado. Ciência Rural, 38(6), 1790-1793. http://dx.doi.org/10.1590/S0103-84782008000600051

Singleton, V. L., \& Rossi, J. A. (1965). Colorimetry of total phenolics with phosphomolybdic-phosphotungstic acid reagents. American Journal of Enology and Viticulture, 16(3), 144-158. Retrieved in 2019, October 29, from http://www.ajevonline.org/content/16/3/144

Siriamornpun, S., \& Kaewseejan, N. (2017). Quality, bioactive compounds and antioxidant capacity of selected climacteric fruits with relation to their maturity. Scientia Horticulturae, 221, 33-42. http://dx.doi.org/10.1016/j.scienta.2017.04.020

Sobukola, O. P., Adeniran, O. M., Odedairo, A. A., \& Kajihausa, O. E. (2010). Heavy metal levels of some fruits and leafy vegetables from selected markets in Lagos, Nigeria. African Journal of Food Science, 4(6), 389-393.

Souza, V. R., Pereira, P. A. P., Queiroz, F., Borges, S. V., \& de Deus Souza Carneiro, J. (2012). Determination of bioactive compounds, antioxidant activity and chemical composition of Cerrado Brazilian fruits. Food Chemistry, 134(1), 381-386. http://dx.doi.org/10.1016/j.foodchem.2012.02.191

Suzuki-Sugihara, N., Kishimoto, Y., Saita, E., Taguchi, C., Kobayashi, M., Ichitani, M., Ukawa, Y., Sagesaka, Y. M., Suzuki, E., \& Kondo, K. (2016). Green tea catechins prevent low-density lipoprotein oxidation via their accumulation in low-density lipoprotein particles in humans. Nutrition Research, 36(1), 16-23. PMid:26773777. http://dx.doi.org/10.1016/j.nutres.2015.10.012

Trindade, C. E. P. (2005). Importância dos minerais na alimentação do pré-termo extremo. Jornal de Pediatria, 81(1, Suppl.), S43S51. PMid:15809697. http://dx.doi.org/10.1590/S0021-75572005000200006

Van Breda, S. G. J., Kok, T. M. C. M., \& Van Delft, J. H. M. (2008). Mechanisms of colorectal and lung cancer prevention by vegetables: A genomic approach. The Journal of Nutritional Biochemistry, 19(3), 139-157. PMid:17651960. http://dx.doi.org/10.1016/j.jnutbio.2007.04.002

Vieira, L. M., Sousa, M. S. B., Mancini-Filho, J., \& Lima, A. (2011). Fenólicos totais e capacidade antioxidante in vitro de polpas de frutos tropicais. Revista Brasileira de Fruticultura, 33(3), 888-897. http://dx.doi.org/10.1590/S0100-29452011005000099

Vieira, R. F., Costa, T. S. A., Silva, D. B., Ferreira, F. R., \& Sano, S. M. (2006). Frutas nativas da região Centro-Oeste (1. ed.). Brasília: Embrapa Recursos Genéticos e Biotecnologia.

Funding: CNPq and FAPEMIG. 